\title{
Peningkatan Usaha Budidaya Cacing Tanah di Kecamatan Teras Kabupaten Boyolali
}

\author{
Rr. Aulia Qonita* dan Erlyna Wida Riptanti \\ Program Studi Agribisnis, Fakultas Pertanian, Universitas Sebelas Maret \\ *Correspoding Author : radenrara@ @taff.uns.ac.id \\ Dikirim: 15-12-2020; Diterima: 10-09-2021
}

\begin{abstract}
ABSTRAK
Cacing tanah merupakan hewan avertebrata, bertubuh lunak dan bermanfaat sebagai organisme pengurai, penghasil pupuk dari limbah organik dan sumber protein hewani. Cacing tanah memiliki nilai ekonomi tinggi. Tujuan pengabdian ialah meningkatkan kapasitas usaha budidaya cacing tanah melalui perbaikan pakan, pemanfaatan kascing dan perbaikan pembukuan usaha pada mitra Usaha Kecil Mikro (UKM) Bambang Sutejo dan Mardi. Metode pengabdian adalah sosialisasi, pelatihan dan pendampingan. Kegiatan pengabdian yang dilaksanakan meliputi pelatihan budidaya cacing tanah, mengintroduksikan ampas aren dan ampas tahu sebagai media (pakan) cacing, pemanfaatan kascing sebagai pupuk organik, pelatihan pembukuan secara sederhana dan pendampingan. Hasil kegiatan mampu meningkatkan kapasitas produksi cacing tanah sebesar $50-70 \%$ per dua bulan. Mitra memiliki media (pakan) alternatif lain yaitu ampas aren dan ampas tahu untuk budidaya cacing. Mitra sudah memanfaatkan kascing sebagai pupuk organik. Mitra memiliki pembukuan sederhana, karena sudah melaksanakan pencatatan terhadap pemasukan dan pengeluaran keuangan usaha budidaya cacing tanah. Kegiatan pengabdian telah memberikan tambahan ilmu pengetahuan dan peningkatan perekonomian mitra.
\end{abstract}

Kata kunci: ampas tahu, media, pakan, kascing

\section{Increasing of Earthworm Cultivation Business in Teras District Boyolali Regency}

\begin{abstract}
Earthworms are soft-bodied, invertebrates, and have many functions as decomposer organisms, fertilizer producers from organic waste, and animal protein sources. Earthworms have high economic value. This community service aims to increase the capacity of earthworm cultivation through improved feed, use of vermicompost, and improvement of business bookkeeping on partner SMEs. The community service method is socialization, earthworm cultivation training, the introduction of media (feed), bookkeeping management training, and mentoring. Community service activities are earthworm cultivation training, introducing palm dregs and tofu dregs as media (feed), vermicompost as organic fertilizer, simple bookkeeping training, and mentoring. This community service activity can increase earthworms' production capacity by 50 - 70\% per two months. SMEs have other alternative media (feed), namely palm dregs and tofu dregs, for worm cultivation. SMEs are already using vermicompost as organic fertilizer. SMEs have simple bookkeeping because they have recorded the financial income and expenditure of earthworm cultivation. Overall, this service activity has provided additional knowledge for SMEs to run a business so that the business is expected to progress and develop.
\end{abstract}

Keywords: dregs, media, feed, vermicompost

\section{PENDAHULUAN}

Cacing tanah adalah hewan yang
termasuk golongan tingkat
rendah yang

termasuk avertebrata atau tidak mempunyai tulang belakang, serta memiliki tubuh yang lunak. Cacing dapat dikategorikan dalam filum Annelida sebab semua bagian tubuh tersusun 
atas sejumlah ruas atau segmen yang memiliki bentuk menyerupai cincin. Disebut dengan cacing tanah atau earthworm karena hewan ini banyak menghabiskan hidupnya di dalam tanah (Khairuman \& Amri, 2009). Menurut Mubarok and Zalidar (2003) cacing tanah memiliki fungsi sebagai berikut: (1) cacing dapat menjadi pengurai bahan organik yang ada di dalam pengolahan limbah padat; (2) cacing sebagai sumber penghasil pupuk limbah organik; (3) cacing merupakan bahan baku sumber protein hewani sekitar $64 \%$ sampai $72 \%$. Selain itu, cacing tanah juga sebagai sumber asam amino esensial untuk berbagai hal, antara lain : (a) sebagai bahan utama di dalam pembuatan pakan ternak, ikan, dan udang; (b) sebagai bahan utama pembuatan pangan; dan (c) sebagai bahan utama pembuatan kosmetik dan obat-obatan.

Cacing tanah bernilai ekonomi tinggi karena bisa dijual dan mendatangkan keuntungan bagi pembudidaya. Budidaya cacing tanah mempunyai prospek yang cukup bagus karena sangat mudah untuk dipelajari (Chilmawati et al., 2014). Untuk membudidayakan cacing tanah hanya memerlukan tanah dan kompos sehingga bisa dikatakan relatif mudah dilaksanakan, efisien dan murah (Ernawati et al., 2017). Budidaya cacing tanah tidak memerlukan banyak waktu karena hanya meluangkan waktu untuk memberi makan serta waktu untuk memanen cacing. Kandang juga tidak perlu dibersihkan secara intensif sebab kascing atau kotoran cacing merupakan salah satu jenis pupuk organik yang berkualitas (Rusmini et al., 2016). Budidaya cacing tanah telah dilakukan oleh UKM Bambang Sutejo dan UKM Mardi.

Usaha Kecil Mikro (UKM) milik Bambang Sutejo dan Mardi merupakan mitra dalam kegiatan pengabdian yang beralamat di Dukuh Kestalan, Nepen, Teras, Boyolali dan di Dukuh Lebak, Nepen, Teras, Boyolali. Selama ini kedua UKM dalam melaksanakan budidaya cacing tanah masih sesuai pengetahuan mereka saja. Hal tersebut menyebabkan proses budidaya menjadi lebih lama dan cacing tidak dapat gemuk atau besar dan jumlahnya sedikit sehingga tidak bisa segera dipanen ketika waktu sudah memasuki masa panen. UKM Bambang Sutejo setiap 3 hari dapat memanen cacing sebanyak kurang lebih $7 \mathrm{~kg}$, sehingga selama 2 bulan menghasilkan kurang lebih $140 \mathrm{~kg}$ cacing. UKM Mardi setiap 3 hari dapat memanen cacing sebanyak $5 \mathrm{~kg}$, sehingga selama 2 bulan dapat menghasilkan kurang lebih $100 \mathrm{~kg}$ cacing.
Sementara itu permintaan cacing tanah cukup banyak dan terkadang tidak mampu memenuhi permintaan, karena cacing yang dihasilkan tidak cepat gemuk sehingga tingkat produktivitasnya masih rendah. Permintaan cacing setiap minggu berkisar antara $35-38 \mathrm{~kg}$, sehingga selama 2 bulan jumlah permintaan sekitar $280-300 \mathrm{~kg}$.

Mitra di dalam melakukan budidaya cacing tanah menggunakan media (pakan) yang berasal dari nasi basi atau "nasi wadang". Selain itu kadang juga menggunakan media (pakan) cacing tanah yang berasal dari limbah di pasar yang beraneka ragam macamnya yaitu sayuran dan buah yang terkadang tercampur plastik. Media-media ini tidak dilakukan fermentasi terlebih dahulu sehingga mengalami proses pembusukan bersama cacing. Hal ini menyebabkan cacing ikut mati. Selain itu cacing yang dihasilkan tidak cepat gemuk sehingga tingkat produktivitasnya masih rendah.

Bekas cacing atau kascing yang mengandung banyak unsur hara, selama ini belum dimanfaatkan oleh kedua UKM. UKM langsung membuang kascing begitu saja setelah melakukan panen cacing tanah atau penggantian media (pakan). Padahal kascing bisa dimanfaatkan sebagai pupuk organik atau dijual untuk menambah penghasilan.

Berdasarkan uraian tersebut, permasalahan yang dijumpai oleh kedua mitra adalah (1) produktivitas cacing yang masih rendah, (2) belum dimanfaatkan bekas cacing atau kascing, dan (3) belum dilaksanakan pembukuan usaha. Oleh sebab itu pengabdian kepada masyarakat ini bertujuan untuk (1) meningkatkan kapasitas usaha budidaya cacing tanah melalui perbaikan pakan (media) supaya cacing menjadi cepat gemuk dan produktivitas cacing menjadi meningkat, (2) pemanfaatan kascing sebagai pupuk organik, dan (3) pelatihan pembukuan usaha pada kedua mitra supaya membuat pembukuan untuk mengetahui secara jelas pengeluaran dan pendapatan usaha budidaya cacing tanah.

\section{METODE}

Kegiatan pengabdian masyarakat dilaksanakan pada pada bulan Juli sampai September 2017 di UKM Bambang Sutejo dan UKM Mardi di Teras Boyolali. Kedua UKM menghadapi beberapa masalah yang telah diidentifikasi. Solusi yang ditawarkan adalah peningkatan keterampilan budidaya cacing tanah untuk meningkatkan produktivitas melalui 
pelatihan budidaya cacing tanah dan pemanfaatan kascing, serta pelatihan pembukuan sederhana dan pendampingan. Metode yang digunakan untuk melaksanakan kegiatan pengabdian adalah sebagai berikut:

\section{Pelatihan tentang budidaya cacing tanah dan pemanfaatan kascing}

Pada pelatihan budidaya cacing tanah untuk 2 UKM memerlukan bahan cacing tanah berupa bibit cacing tanah sebanyak $40 \mathrm{~kg}, 30$ karung ampas aren, 20 karung ampas tahu, susu pedet, EM4 dan tetes tebu. Alat yang diperlukan adalah tempat (wadah) media cacing, tempat (wadah) fermentasi media, botol semprot, dan pisau pencacah. Cara pembuatan media (pakan) adalah dengan memotong atau menghaluskan media menjadi ukuran yang kecil, kemudian dilakukan fermentasi dengan menambahkan EM4 atau tetes tebu selama 14 hari. Cara pemberian pakan adalah dengan perbandingan 1:20, artinya apabila bibit cacing sebanyak $1 \mathrm{~kg}$ maka media sebanyak $20 \mathrm{~kg}$. Media apabila sudah berubah wujud menjadi kascing (seperti tanah) maka harus ditambah atau diganti dengan media yang baru. Pemeliharaan dilakukan dengan cara membalik posisi dan mengganti media apabila sudah berubah jadi kascing, kemudian menyemprot media dengan susu pedet sebanyak dua kali seminggu. Panen cacing bisa dilakukan secara berulang setiap bulan selama 6 bulan dengan cara mengambil dan memilih cacing yang memiliki ukuran besar yang siap untuk dipanen. Pelatihan budidaya ini juga menjelaskan tentang kascing dan cara pemanfaatan kascing sebagai pupuk organik.

\section{Introduksi ampas aren dan ampas tahu sebagai media cacing}

Selama ini kedua UKM mitra belum pernah menggunakan ampas aren dan ampas tahu yang mudah diperoleh di sekitar lokasi budidaya cacing tanah. Limbah ampas tahu mempunyai kandungan protein tinggi (Selpiana et al., 2016). Ampas aren dan ampas tahu sebelum digunakan untuk media (pakan) juga perlu dilakukan fermentasi terlebih dahulu.

\section{Pelatihan manajemen pembukuan}

Pelatihan manajemen pembukuan pada kedua UKM mitra dengan pembukuan keuangan sederhana dan praktis yaitu jenis pencatatan keuangan yang mudah dimengerti dan mudah dipraktikan. Pelatihan dimulai dengan mengajarkan cara mengidentifikasi pemasukan dan pengeluaran serta menghitung keuntungan usaha (Qonita et al., 2019).

\section{Pendampingan UKM}

Pendampingan kepada UKM dilakukan dengan cara melihat dan memantau perkembangan UKM terkait hal-hal yang sudah dilatihkan dan diintroduksikan. Pendampingan usaha juga bertujuan memberikan solusi terhadap permasalahan-permasalahan yang muncul selama kegiatan pengabdian ini berlangsung (Qonita et al., 2018).

\section{HASIL DAN PEMBAHASAN}

\section{Sosialisasi}

Sosialisasi kegiatan dilaksanakan di kediaman Bapak Bambang Sutejo karena lokasi UKM Bambang Sutejo dan UKM Mardi berdekatan, yaitu hanya berjarak 200 meter. Sosialisasi dilaksanakan untuk menyampaikan program-program kegiatan yang akan diselenggarakan oleh Tim Pengabdi kepada kedua mitra dan kesepakatan penjadwalan kegiatan. Program-program kegiatan disampaikan secara terperinci, agar kedua mitra paham dan dapat mempersiapkan hal-hal yang mendukung terselenggaranya kegiatan pengabdian.

\section{Pelatihan budidaya cacing tanah yang baik dan benar}

UKM Bambang Sutejo dan UKM Mardi selama 2 bulan menghasilkan kurang lebih 240 $\mathrm{kg}$ cacing. Permintaan cacing selama 2 bulan berjumlah sekitar $280-300 \mathrm{~kg}$. Jumlah permintaan tidak dapat dipenuhi karena cacing tidak cepat gemuk dan proses budidaya memerlukan waktu yang lama. Hal tersebut karena kedua mitra dalam melaksanakan budidaya cacing tanah belum secara intensif. Kedua mitra berpikir bahwa yang penting usaha sudah dapat berjalan, produk dapat dijual dan mendapatkan uang. Pada kegiatan pelatihan budidaya cacing ini, Tim Pengabdi mengundang narasumber dari Prodi Ilmu Tanah Fakultas Pertanian Universitas Sebelas Maret yaitu Dr. Ir. Widyatmani Sih Dewi, M.P. untuk memberikan materi tentang budidaya cacing tanah yang baik dan benar.

Selama ini kedua mitra dalam melakukan budidaya cacing tanah masih menggunakan media (pakan) seperti limbah rumah tangga yaitu nasi basi atau "nasi wadang" (Gambar 1) dan limbah pasar seperti sisa sayur dan buah dalam - 


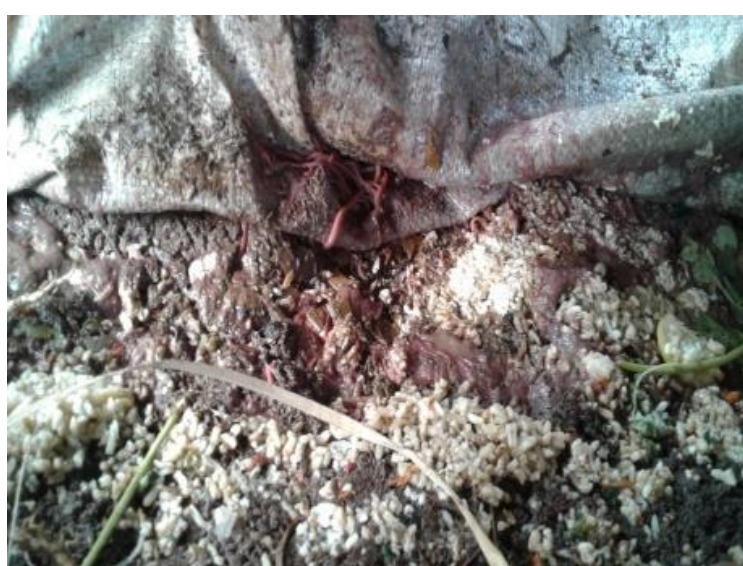

Gambar 1. Media (Pakan) cacing dari nasi basi atau nasi wadang

bentuk segar yang belum difermentasi terlebih dahulu (Gambar 2). Hal tersebut bisa menyebabkan cacing menjadi mati, cacing menjadi kurus dan pertumbuhan cacing tanah tidak maksimal.

Berdasarkan kondisi tersebut, kedua mitra disarankan untuk tidak memberi cacing dengan media (pakan) yang segar, harus difermentasi terlebih dahulu. Fermentasi ini bertujuan menurunkan kadar karbon dan meningkatkan kadar nitrogen. Fermentasi dimulai dengan memotong atau menghaluskan limbah rumah tangga berupa sayur dan buah dengan pisau, kemudian dimasukkan ke dalam wadah atau ember, lalu bisa diberi air yang telah dicampur EM4 dan tetes tebu secukupnya, kemudian diaduk sampai merata dan ember ditutup selama kurang lebih 14 hari. Hasil fermentasi dikatakan baik apabila memiliki bau asam dan tidak berbau busuk (Gambar 3). Proses fermentasi perlu dicampur dengan tetes tebu karena menurut Yunitasari et al. (2016), tetes tebu memiliki fungsi untuk meningkatkan nafsu makan cacing tanah. Menurut Maulida (2015) pakan cacing tanah perlu dilakukan fermentasi dengan tujuan membuat agar tekstur makanan menjadi lebih lunak, dapat mempertinggi daya serap terhadap makanan, serta mempertinggi kandungan nutrisi pada makanan.

Selain media yang lunak dan segar, media cacing bisa berasal dari bahan yang berwujud keras misalnya cangkang telur atau tulang-tulang ayam. Untuk itu cangkang telur atau tulang ayam harus dipresto terlebih dahulu dengan menggunakan panci presto. Dengan memanfaatkan uap air yang bertekanan tinggi pada panci presto dapat membuat cangkang telur dan tulang ayam menjadi lunak dan lembut, sehingga proses fermentasi akan lebih mudah dan lebih baik.

Narasumber juga mengintroduksikan untuk menggunakan media yang berasal dari limbah industri pati aren. Limbah tersebut berupa ampas aren yang bisa dijadikan sebagai media pertumbuhan untuk usaha ternak cacing tanah. Penggunaan ampas aren sebagai media juga merupakan salah satu cara untuk untuk mengurangi limbah industri aren. Menurut Lokaningrum et al. (2017), limbah yang dihasilkan dari industri pembuatan tepung aren untuk bahan baku pembuatan mie bihun disebut onggok aren. Onggok aren dapat digunakan sebagai tempat media hidup untuk cacing tanah. Menurut Sudargana et al. (2009), ampas ongok aren adalah limbah pertanian yang tidak mudah untuk diolah karena memiliki kandungan serat yang kaku yang dapat membahayakan kulit apabila dipakai untuk pupuk organik. Selain itu ampas pati mengandung banyak air yang akan sulit dikeringkan apabila dipakai untuk bahan bakar. Sementara ini, onggok aren hanya dimanfaatkan sebagai media hidup di dalam budidaya cacing.

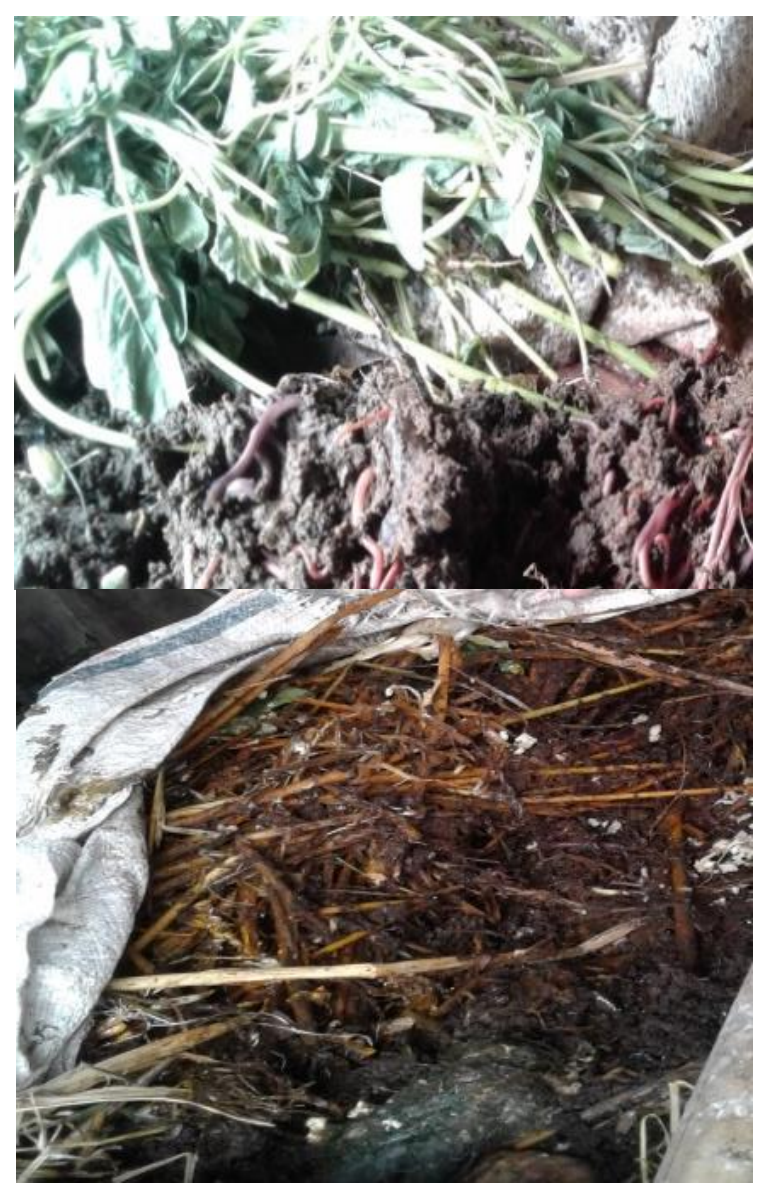

Gambar 2. Media cacing dari limbah pasar 


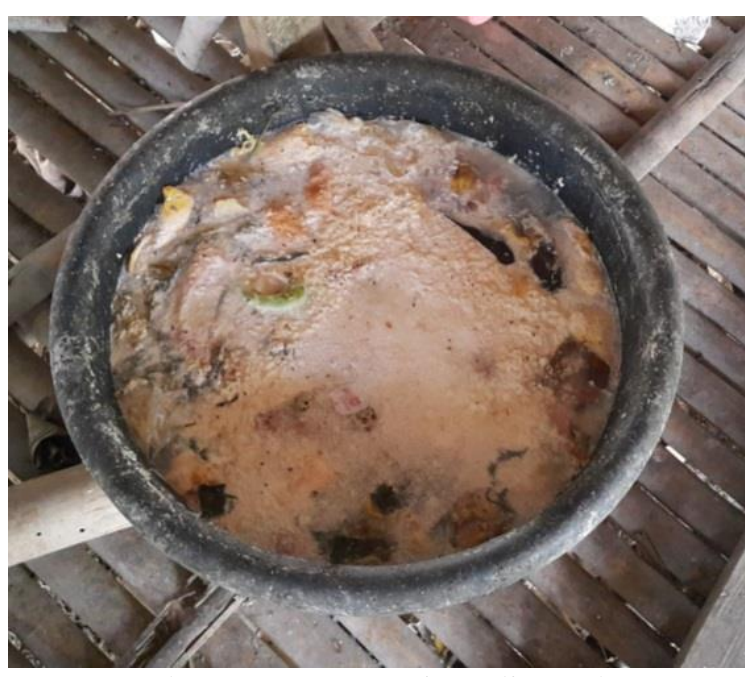

Gambar 3. Fermentasi media (pakan)

Narasumber juga menjelaskan bahwa selain ampas aren bisa juga menggunakan ampas tahu. Menurut Suwahyono and Tim Penulis PS (2014) menyebutkan bahwa ampas tahu adalah limbah dalam bentuk padat yang dihasilkan oleh industri tahu. Limbah tahu mengandung unsur nitrogen dan mineral. Menurut Hernaman and Hidayat (2005), hasil analisis laboratorium menunjukkan bahwa ampas tahu terdiri dari $8,69 \%$ bahan kering; $18,67 \%$ protein kasar; 24,43\% serat kasar; 9,43\% lemak kasar; 3,42\% abu dan 41,97\% BETN. Berdasarkan komposisi, ampas tahu mempunyai kadar protein tinggi, mengandung banyak air dan bahan kering yang rendah. Tingginya protein dan air yang ada di dalam ampas tahu menyebabkan cepat terjadi pembusukan sehingga tidak bisa disimpan.

Media pakan bisa digunakan sebagai tempat hidup cacing dengan ukuran ideal sebesar 20 banding 1 . Artinya cacing yang digunakan sebagai bibit adalah 1 bagian berbanding dengan media sebanyak 20 bagian. Misalkan media yang digunakan sebanyak $20 \mathrm{~kg}$ maka dikombinasikan dengan bibit cacing sebanyak 1 $\mathrm{kg}$.

Pelatihan tersebut juga menjelaskan bahwa cacing tanah memerlukan media dengan tingkat kelembapan sebesar $60 \%$. Kelembapan bisa dicek dengan cara menggenggam dan meremas media (pakan) dengan telapak tangan maka dari genggaman dan remasan tersebut masih akan ada air yang keluar dari sela-sela jari. Hal itu yang menandakan bahwa kelembapan sudah sekitar $60 \%$. Media cacing harus dibalik setiap satu minggu sekali agar dapat tercampur secara merata. Apabila media cacing sudah menjadi seperti tanah atau sudah berupa kascing atau sudah terlihat banyak kokon (telur cacing) maka media perlu diganti dengan yang baru. Hal tersebut dilakukan agar cacing dapat hidup dan berkembang dengan baik. Menurut Primaturrismaa and Dhokhikah (2020), kelembapan merupakan hal yang penting bagi cacing agar dapat mempertahankan cadangan air di dalam tubuh. Cacing tanah menghendaki kelembapan antara $60 \%$ - 90\%. Di samping kondisi tempat yang lembap, kehidupan cacing juga dipengaruhi oleh kondisi tanah yang meliputi jenis tanah, temperatur, $\mathrm{pH}$ atau keasaman tanah, aerasi, karbondioksida, bahan organik, dan suplai makanan. Faktor terpenting adalah $\mathrm{pH}$ tanah dan bahan organik. $\mathrm{pH}$ tanah yang optimal berkisar antara 6,5 - 8,5. Suhu ideal sekitar $21^{\circ} \mathrm{C}-30^{\circ} \mathrm{C}$.

Cacing tanah bisa dipanen beberapa kali, namun biasanya dipanen satu bulan sekali dengan masa panen sekitar 6 bulan pemeliharaan. Biasanya ketika panen akan terdapat kokon atau telur-telur cacing yang dapat dibudidayakan kembali. Media cacing tanah setelah sekitar 6 bulan akan berubah warna menjadi kecokelatan seperti tanah, yang dinamakan kascing atau bekas cacing (Gambar 4).

Gambar 4 adalah kascing atau bekas kascing yang dihasilkan oleh kedua mitra. Bekas cacing (kascing) yang seperti tanah bisa digunakan sebagai pupuk organik. Selama ini kedua mitra tidak pernah memanfaatkan kascing sebagai pupuk organik. Mereka hanya membuang begitu saja kascing tersebut karena tidak tahu akan manfaat dari kascing. Melalui pelatihan budidaya disebutkan bahwa kascing dapat digunakan sebagai pupuk organik bagi tanaman. Menurut Susilorini et al. (2008), kascing merupakan kotoran budidaya cacing tanah yang diperoleh dari sisa mencerna media (pakan) bahan organik yang berwujud partikelpartikel tanah yang memiliki warna kehitaman dengan ukuran yang lebih kecil apabila dibandingkan dengan partikel tanah biasa. Menurut Simanjuntak (2004), kascing atau bekas cacing ialah bahan organik hasil sampingan dari budidaya cacing berupa kotoran cacing yang telah bercampur dengan bahan organik lain maupun tanah. Pupuk kascing memiliki kandungan unsur hara $\mathrm{N}, \mathrm{P}, \mathrm{K}, \mathrm{Ca}, \mathrm{Mg}$, $\mathrm{S}, \mathrm{Fe}$ serta unsur lainnya yang diperlukan oleh tanaman. Pupuk kascing memiliki $\mathrm{pH}$ netral antara $5-7,4$ dengan rata-rata 6,9. Pupuk kascing merupakan salah satu jenis bahan organik yang mempunyai manfaat baik karena bisa digunakan untuk memperbaiki sifat fisik, kimia maupun biologi tanah, terutama pada tanah yang tingkat kesuburannya masih kurang. Kascing memiliki kandungan hara maupun kandungan kimia yang banyak jenisnya dibandingkan dengan pupuk kompos maupun pupuk organik yang lain. 


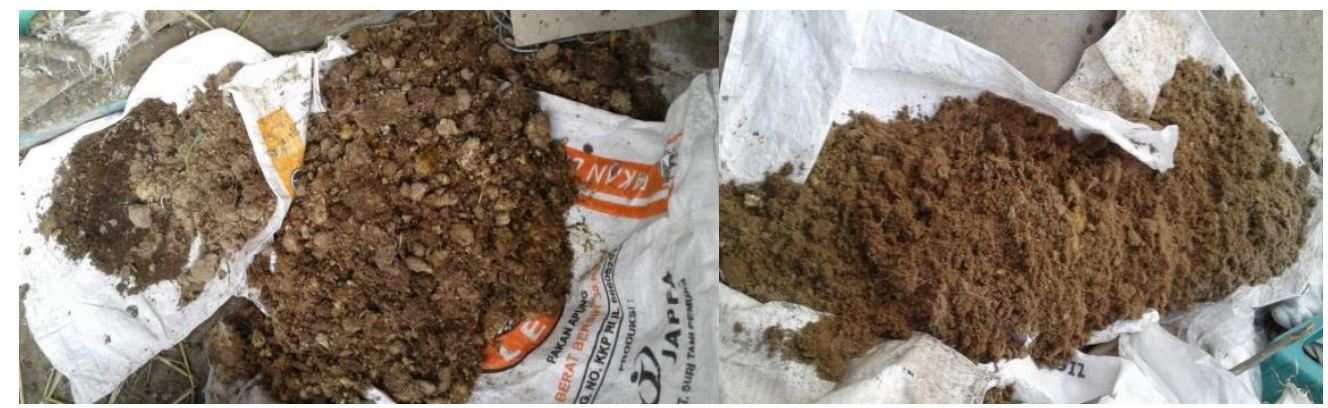

Gambar 4. Kascing yang dihasilkan kedua UKM

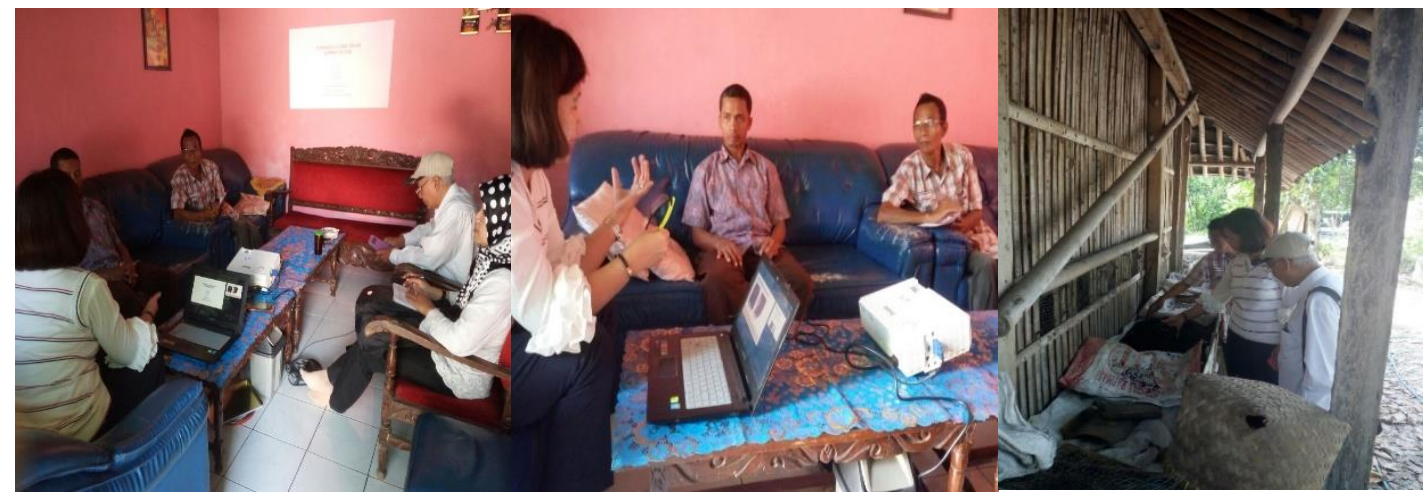

Gambar 5. Pelatihan budidaya cacing tanah di kedua mitra

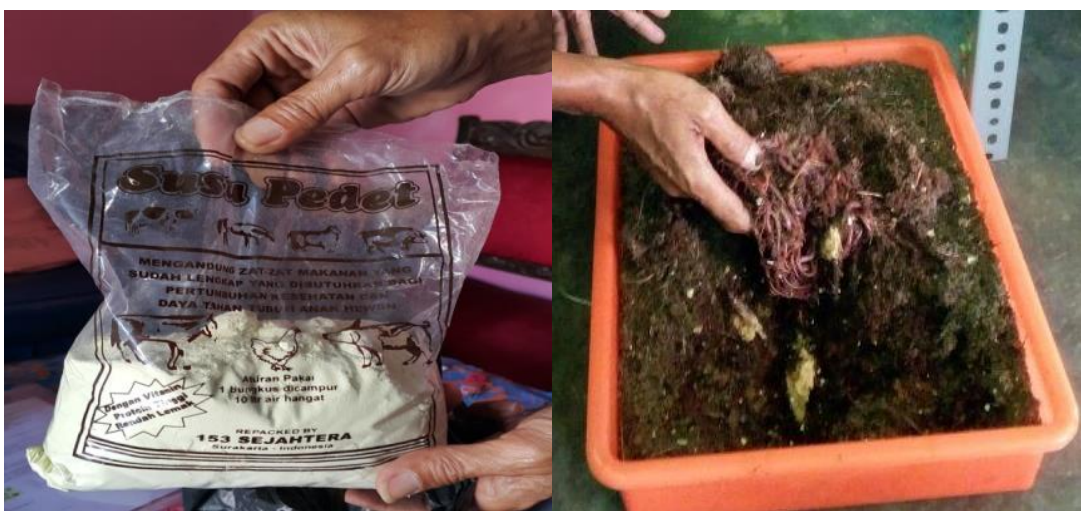

Gambar 6. Susu pedet yang digunakan mitra dan hasil produksi cacing tanah

Gambar 5 menunjukkan mitra sedang mengikuti pelatihan budidaya cacing tanah. Mereka mendapat banyak pengetahuan tentang cara-cara budidaya dan pemanfaatan kascing, dan bertekad untuk menjalankan usaha dengan sepenuh hati. Selain itu di dalam penggunaan media yang berasal dari ampas aren atau ampas tahu, kedua mitra juga menggunakan susu pedet (Gambar 6). Susu pedet adalah susu yang dipergunakan untuk hewan ternak misalkan kambing maupun sapi. Susu pedet diaplikasikan dengan cara disemprotkan sebanyak $100 \mathrm{ml}$ seminggu 2 kali pada media (pakan) cacing tanah (Gambar 6).

Berdasarkan hasil pengamatan pada Gambar 6 menunjukkan bahwa budidaya dengan menggunakan media ampas aren atau media ampas tahu yang disemprot dengan susu pedet dapat meningkatkan hasil produksi cacing tanah. Semula ketika menggunakan media seadanya yaitu sampah rumah tangga atau nasi wadang dengan bibit cacing tanah sebanyak $10 \mathrm{~kg}$ hanya dapat memanen cacing tanah sebanyak $20 \mathrm{~kg}$ dan yang $10 \mathrm{~kg}$ cacing tanah lagi ditaburkan sebagai bibit periode selanjutnya. Dengan demikian panen bersih yang diterima adalah $10 \mathrm{~kg}$ cacing tanah dalam jangka waktu 2 bulan. Namun sejak menggunakan media ampas aren atau ampas tahu yang disemprot dengan susu pedet, kedua mitra mengalami peningkatan hasil panen. Untuk UKM Bambang Sutejo dengan bibit per $10 \mathrm{~kg}$ dapat menghasilkan $27 \mathrm{~kg}$ cacing tanah dan yang ditaburkan jadi bibit sebanyak $10 \mathrm{~kg}$, sehingga dapat panen sebanyak $17 \mathrm{~kg}$. Untuk 
UKM Mardi dengan bibit per $10 \mathrm{~kg}$ dapat menghasilkan $25 \mathrm{~kg}$ cacing tanah dan ditaburkan kembali jadi bibit sebanyak $10 \mathrm{~kg}$, sehingga dapat panen $15 \mathrm{~kg}$. Selama 2 bulan UKM Bambang Sutejo dapat memanen sebanyak 225 $\mathrm{kg}$ dan UKM Mardi memanen sebanyak $150 \mathrm{~kg}$. Adanya perbedaan hasil panen antara UKM Bambang Sutejo dan UKM Mardi bisa karena kelembapan media cacing tanah yang digunakan, suhu udara, tingkat kegelapan, dan ketekunan dalam membalik media cacing tanah. Kondisi ideal untuk media cacing tanah adalah yang memiliki kelembapan $60 \%$, suhu udara tidak lebih dari $28^{\circ} \mathrm{C}$, lebih menyukai kondisi yang gelap dan pentingnya membalik media cacing tanah seminggu sekali. Ada perbedaan antara sebelum kegiatan pengabdian dan sesudah pengabdian adalah adanya peningkatan hasil produksi sekitar $40-50 \%$. Selain itu berdasarkan hasil panen menunjukkan bahwa UKM Bambang Sutejo lebih produktif dibandingkan UKM Mardi, karena dengan jumlah bibit yang digunakan adalah sama, namun hasil panen UKM Bambang Sutejo lebih banyak.

Pemanfaatan kascing digunakan untuk memenuhi kebutuhan pupuk organik yang digunakan untuk budidaya tanaman jagung di lahan kedua mitra. Kedua mitra dapat menghemat biaya pembelian pupuk anorganik berkisar antara Rp200.000 sampai Rp300.000 untuk sekali periode tanam jagung. Hal ini dapat menghemat biaya produksi usahatani jagung karena menggunakan pupuk yang dihasilkan dari budidaya cacing.

\section{Pelatihan Pembukuan Keuangan Secara Sederhana pada Kedua UKM}

Pada umumnya suatu usaha akan mempunyai transaksi keuangan yang terjadi setiap hari. Agar keuangan dapat dikelola dengan baik maka pencatatan keuangan harus dilakukan oleh pemilik usaha, agar dapat melihat biaya yang masuk dan biaya yang keluar. Pencatatan keuangan yang baik dapat mempengaruhi keberhasilan usaha yang dikelola dan dijalankan. Proses kegiatan pencatatan terhadap keuangan yang masuk dan keluar disebut dengan proses pembukuan (Widiastuti et al., 2018).

Pelatihan pembukuan yang diberikan kepada kedua mitra adalah pelatihan pembukuan sederhana (Gambar 7). Pembukuan dilakukan sebagai suatu proses untuk mencatat, meringkas

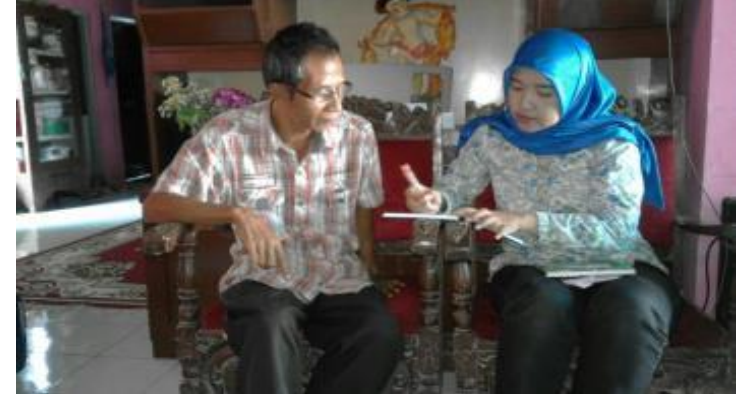

Gambar 7. Pelatihan dalam pembukuan keuangan secara sederhana

transaksi-transaksi keuangan yang dilaksanakan oleh UKM mitra, baik transaksi pemasukan maupun transaksi pengeluaran Berdasarkan hal tersebut bisa diketahui keuntungan maupun kerugian yang diperoleh UKM mitra selama menjalankan usaha. Pembukuan meskipun hanya sederhana namun merupakan sesuatu yang penting. Hal tersebut dikarenakan dengan adanya pencatatan keuangan dapat memberikan data kepada pemilik UKM yang sewaktu-waktu bisa diperlukan. Qonita et al. (2018) menyatakan bahwa pencatatan keuangan perlu dilaksanakan karena manusia memiliki kemampuan yang terbatas di dalam mengingat transaksi-transaksi yang pernah terjadi.

Permasalahan umum yang dihadapi oleh UKM mitra maupun UKM yang lain, adalah para pelaku usaha ini enggan untuk melakukan pencatatan terhadap transaksi-transaksi pemasukan maupun pengeluaran karena berbagai alasan. Alasannya antara lain keuangan usaha dengan keuangan rumah tangga tercampur menjadi satu, mereka merasa belum perlu untuk mencatat pemasukan dan pengeluaran karena yang penting usaha sudah bisa berjalan, juga tidak mau direpotkan dengan kegiatan catat mencatat karena akan menambah pekerjaan.

Gambar 7 menunjukkan kegiatan pelatihan pembukuan keuangan secara sederhana. Kegiatan pelatihan pembukuan sederhana diharapkan dapat meningkatkan pengetahuan kedua mitra tentang pembukuan dan mitra mau melaksanakan pembukuan meskipun secara sederhana terhadap transaksi keuangan yang terjadi dalam usahanya. Selain itu kedua mitra bisa memisahkan antara keuangan rumah tangga dan keuangan usaha. Catatan pembukuan sederhana menunjukkan berapa besar uang usaha yang ada sehingga bisa mengetahui apakah usaha yang dilakukan tersebut mengalami keuntungan, kerugian atau impas. mitra dapat mengetahui adanya 


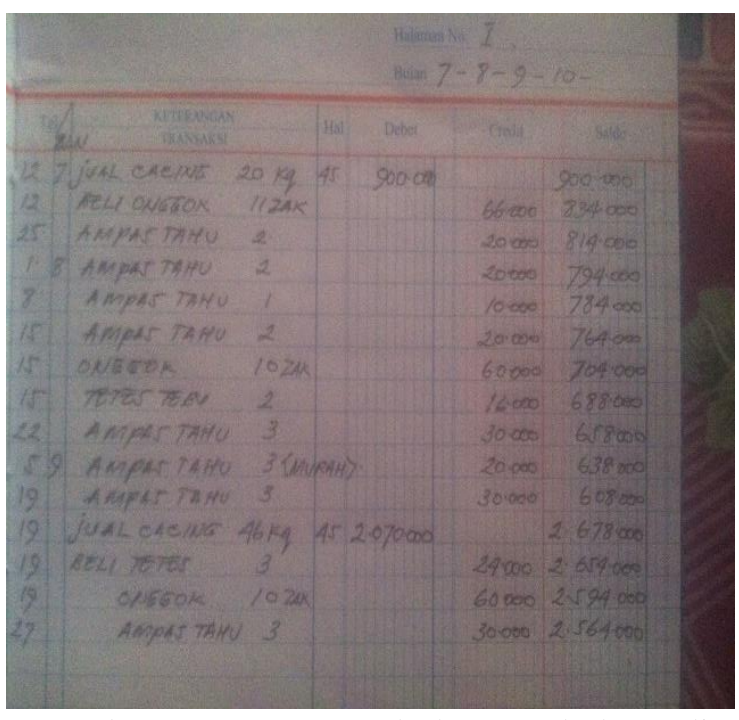

Gambar 8. Catatan pembukuan sederhana di UKM Bambang Sutejo

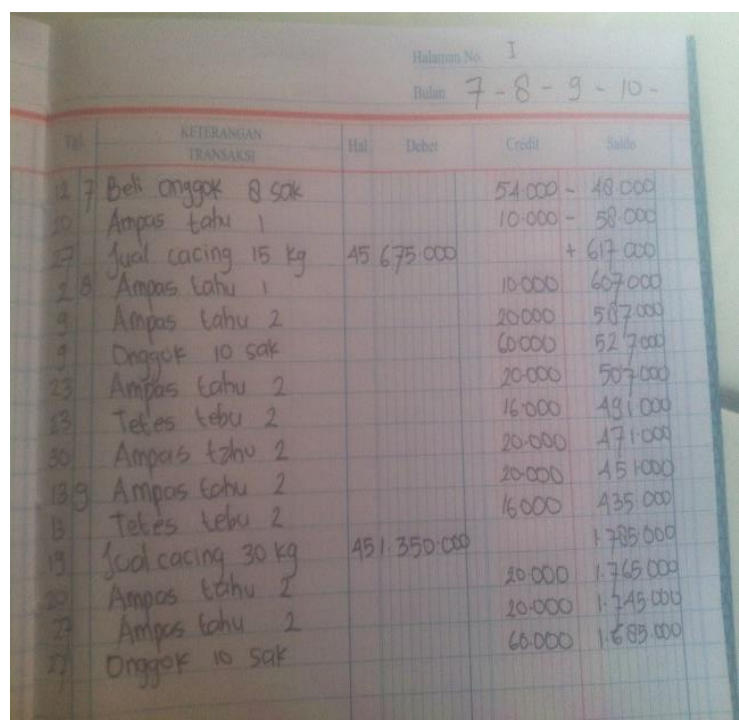

Gambar 9. Catatan pembukuan sederhana di UKM Mardi

keuntungan atau kerugian yang dialami sehingga dapat dipakai sebagai acuan dalam perencanaan usaha dan pengambilan keputusan terkait pengembangan usaha budidaya cacing tanah untuk masa yang akan datang. Pencatatan pembukuan juga dapat digunakan untuk mendeteksi kendala yang dihadapi dalam usaha dan mengetahui cara mengatasi kendala tersebut.

Pada saat monitoring diketahui bahwa kedua mitra telah melakukan pembukuan walaupun belum menuliskan secara detail. Gambar 8 menunjukkan hasil catatan pembukuan yang dilakukan oleh UKM Bambag Sutejo. Gambar 9 menunjukkan hasil catatan pembukuan yang dilakukan oleh UKM Mardi. Hal ini menunjukkan bahwa ada tingkat kemajuan dan kemauan mitra di dalam melakukan pembukuan. Sebelum ada kegiatan pelatihan kedua mitra belum tahu tentang pembukuan sehingga tidak melaksanakan pembukuan. Namun, setelah ada kegiatan pelatihan pembukuan, kedua mitra jadi tahu tentang pembukuan dan mau melaksanakan pembukuan. Berarti ada peningkatan pengetahuan dan kemauan dari kedua mitra.

\section{Pendampingan Usaha}

Pendampingan terhadap kedua mitra dilakukan oleh Tim Pengabdi dengan tujuan memantau kegiatan UKM terkait dengan hal-hal yang sudah dilatihkan dan diintroduksikan sehingga diharapkan UKM bisa menjadi mandiri dan sukses. Pendampingan meliputi: (1) pendampingan saat proses fermentasi media untuk cacing tanah agar hasil fermentasinya berkualitas bagus dan tidak mengalami busuk, (2) pendampingan di dalam penggunaan media (pakan) cacing yang berasal dari ampas aren dan ampas tahu, sebagai media alternatif selain nasi wadang dan limbah pasar, (3) pendampingan di dalam pemanfaatan kascing untuk pupuk organik, dan (4) pendampingan di dalam pencatatan pembukuan sederhana agar dapat diketahui besar pengeluaran dan penerimaan usaha.

\section{Dampak dan Manfaat Kegiatan}

Kegiatan pengabdian ini sudah memberikan dampak serta manfaat untuk UKM. UKM mengalami peningkatan pengetahuan tentang cara budidaya yang baik dan benar, terutama terkait proses fermentasi media sehingga terjadi peningkatan kapasitas produksi cacing sebesar $50-70 \%$ per dua bulan. UKM memperoleh tambahan pengetahuan tentang media alternatif lain yaitu ampas aren dan ampas tahu yang dapat digunakan untuk budidaya cacing. UKM yang semula tidak mengetahui bahwa ampas aren dan ampas tahu dapat digunakan sebagai media menjadi mengetahui kalau limbah tersebut dapat digunakan sebagai media selain limbah rumah tangga dan limbah pasar. UKM mengalami peningkatan pengetahuan tentang kascing yang dapat digunakan untuk pupuk organik. UKM semula tidak tidak mengetahui tentang kegunaan kascing, menjadi mengetahui manfaat kascing. UKM memperoleh pengetahuan tentang cara pembukuan sederhana sehingga mengetahui arus uang masuk, arus uang keluar dan keuntungan dari usaha budidaya cacing. UKM semuala tidak mengetahui cara pembukuan sederhana, menjadi 
mengetahui cara melakukan pembukuan sederhana, yang dapat terlihat dari hasil catatan pada Gambar 8 dan 9.

\section{KESIMPULAN}

Kegiatan pengabdian dapat meningkatkan kapasitas produksi sebesar $50-70 \%$ per dua bulan, dengan media ampas aren dan ampas tahu yang dikombinasikan dengan susu pedet. UKM sudah memanfaatkan kascing sebagai pupuk organik. UKM memiliki pembukuan sederhana, karena sudah melaksanakan pencatatan terhadap pemasukan dan pengeluaran keuangan usaha budidaya cacing tanah. Berdasarkan kondisi tersebut, diharapkan usaha budidaya cacing tanah bisa semakin maju dan berkembang.

\section{UCAPAN TERIMA KASIH}

Tim Pengabdi menghaturkan terima kasih kepada Lembaga Penelitian dan Pengabdian kepada Masyarakat (LPPM), Universitas Sebelas Maret atas Hibah Pengabdian Tahun 2017 (Surat Perjanjian Pelaksanaan Penugasan Program Pengabdian kepada Masyarakat Nomor: 624/UN27.21/PM/2017). Tim Pengabdi juga menghaturkan terima kasih kepada UKM Bambang Sutejo maupun UKM Mardi yang telah berpartisipasi dalam kegiatan pengabdian sehingga bisa terselenggara dengan baik.

\section{DAFTAR PUSTAKA}

Chilmawati, D., Hutabarat, J., Samijan, I., \& Herawati, P. V. E. (2014). Budidaya cacing tanah sebagai sumber pakan alternatif dalam pemeliharaan lele dumbo di Pondok Pesantren Hidayatullah, Semarang. Saintek Perikanan: Indonesian Journal of Fisheries Science and Technology, 9, 49-52. https://ejournal.undip.ac.id/index.php/saint ek/article/view/8121

Ernawati, N. M., Julyantoro, P. G. S., Suryaningtyas, E. W., Sari, A. H. W., Kartika, G. R. A., Saraswati, S. A., \& Pebriani, D. A. A. (2017). Pelatihan budidaya cacing lumbricus rubellus sebagai alternatif pakan lele berprotein tinggi pada pembudidaya lele di Kec. Abiasemal, Kab. Badung. Buletin Udayana Mengabdi, 16, 179-183.

https://ojs.unud.ac.id/index.php/jum/article /view/36095
Hernaman, I., \& Hidayat, R. (2005). Pengaruh penggunaan molases dalam pembuatan silase campuran ampas tahu dan pucuk tebu kering terhadap nilai $\mathrm{pH}$ dan komposisi zatzat makanannya. Jurnal Ilmu ternak, 5, 9499.

http://jurnal.unpad.ac.id/jurnalilmuternak/a rticle/view/2296

Khairuman, \& Amri, K. (2009). Mengeruk untung dari beternak cacing. PT AgroMedia Pustaka.

Lokaningrum, H., Suhandoyo, \& Ciptono. (2017). Pengaruh kombinasi media onggok aren dan serbuk gergaji batang pohon kelapa terhadap pertumbuhan dan produksi kokon cacing tanah eudrilus eugeniae. Program Studi Biologi UNY, 6(7), 431-440.

Maulida, A. (2015). Budi daya cacing tanah unggul ala adam cacing. PT AgroMedia Pustaka.

Mubarok, A., \& Zalidar, L. (2003). Budidaya cacing tanah sebagai usaha alternatif di masa krisis ekonomi. Jurnal Dedikasi, 1(1), 129-135.

https://ejournal.umm.ac.id/index.php/dedik asi/article/view/923

Primaturrismaa, L., \& Dhokhikah, Y. (2020). Gerilya (Gerakan Inovatif Pengelolaan Limbah Dan Pustaka) : Pengelolaan sampah melalui kegiatan vermikompos dan ecobrick guna menumbuhkan peran masyarakat dalam bidang edukasi dan bidang lingkungan untuk mewujudkan SDGs 2030. Jurnal Proteksi: Jurnal Lingkungan Berkelanjutan, 1(1), 30-38. https://jurnal.unej.ac.id/index.php/PROTE KSI/article/view/20379

Qonita, R. A., Parnanto, N. H. R., \& Riptanti, E. W. (2018). Pemberdayaan usaha keripik singkong rasa gadung. Jurnal Dianmas, 7(3), 201-210. http://jurnaldianmas.org/index.php/Dianma s/article/view/121

Qonita, R. A., Parnato, N. H. R., \& Riptani, E. W. (2019). Prospek penggunaan abu dari limbah pembakaran batu bata dalam usaha pembuatan telur asin. Jurnal Dianmas, $8(3)$,

133-138. http://jurnaldianmas.org/index.php/Dianma s/article/view/171

Rusmini, R., Kusumawati, N., Prahara, M. A., \& Wikandari, P. R. (2016). Pelatihan budidaya cacing tanah (Lumbricus Rubellus) bagi para tani Desa Sumberdukun, Ngariboyo, Magetan. Jurnal 
$A B D I$,

1(2),

114. Suwahyono, U., \& Tim Penulis PS. (2014). https://doi.org/10.26740/ja.v1n2.p114-120

Selpiana, Patricia, \& Anggraeni, C. P. (2016). Pengaruh penambahan kitosan dan gliserol pada pembuatan bioplastik dari ampas tebu dan ampas tahu. Jurnal Teknik Kimia, 22(1), 57-64.

Simanjuntak, D. (2004). Manfaat pupuk organik kascing dan cendawan mikoriza arbuskula (cma) pada tanah dan tanaman. Jurnal Penelitian Bidang Ilmu Pertanian, 2(1), 59.

Sudargana, Syaiful, \& Yohana, E. (2009). Uji deskripsi konduktifitas thermal ampas onggok aren dengan variasi tekanan kompaksi. Rotasi, 11, 21-22. https://ejournal.undip.ac.id/index.php/rotas i/article/view/2017

Susilorini, T., Sawitri, M., \& Muharlien. (2008). Cepat buat Kompos dari Limbah. Penebar Swadaya.

Widiastuti, T. C., Santoso, A., \& Anandha. (2018). Model pembukuan sederhana UKM bakso semi modern di Wilayah Kota Semarang. Jurnal Dinamika Sosial Budaya, 20 , 16-29. https://doi.org/10.26623/jdsb.v20i1.1230 Yunitasari, R., Haji, A. T. S., \& Susanawati, L. D. (2016). Pengaruh pemberian limbah organik kantin terhadap pertumbuhan cacing tanah (Lumbricusrubellus) dengan media sampah daun sekitar Kampus Universitas Brawijaya. Jurnal Sumberdaya Alam dan Lingkungan, 2(3), 27-31. https://jsal.ub.ac.id/index.php/jsal/article/vi $\underline{\text { ew/241 }}$ Budidaya 22 Ternak Potensial. Penebar Swadaya. 